University of Nebraska - Lincoln

DigitalCommons@University of Nebraska - Lincoln

U.S. Environmental Protection Agency Papers

U.S. Environmental Protection Agency

2009

Use of Fenton's Reagent as a Disinfectant

Ariamalar Selvakumar

U.S. Environmental Protection Agency

Mary Ellen Tuccillo

Cadmus Group

Swarna Muthukrishnan

American Water

Asim B. Ray

U.S. Environmental Protection Agency

Follow this and additional works at: https://digitalcommons.unl.edu/usepapapers

Selvakumar, Ariamalar; Tuccillo, Mary Ellen; Muthukrishnan, Swarna; and Ray, Asim B., "Use of Fenton's Reagent as a Disinfectant" (2009). U.S. Environmental Protection Agency Papers. 152.

https://digitalcommons.unl.edu/usepapapers/152

This Article is brought to you for free and open access by the U.S. Environmental Protection Agency at DigitalCommons@University of Nebraska - Lincoln. It has been accepted for inclusion in U.S. Environmental Protection Agency Papers by an authorized administrator of DigitalCommons@University of Nebraska - Lincoln. 


\section{Use of Fenton's Reagent as a Disinfectant}

Ariamalar Selvakumar

Mary Ellen Tuccillo

Swarna Muthukrishnan

Asim B. Ray

Several compositions of Fenton's Reagent and hydrogen peroxide alone were used to disinfect combined sewage samples from a wastewater treatment facility. The presettled samples contained suspended solids (SS) and dissolved organic carbon (DOC) at concentrations of 28 and $290 \mathrm{mg} / \mathrm{L}$, respectively. Disinfection with Fenton's Reagent was carried out at a pH between 5.90 and 6.0 and at a temperature of $25^{\circ} \mathrm{C}$. All disinfected samples contained residual oxidants. Under all reaction conditions studied, complete inactivation of $\mathrm{E}$. coli was achieved within one minute of the addition of Fenton's Reagent. Disinfection with hydrogen peroxide alone under similar conditions is incomplete even under much longer contact times. (C) 2009 Wiley Periodicals, Inc.*

\section{INTRODUCTION}

In a wet-weather event, the combined wet and dry flows in an urban watershed can exceed the treatment capacity of a wastewater treatment system. This exceedance can discharge a mixture of stormwater and raw sanitary wastewater into receiving waters. These discharges generally contain high concentrations of indicator organisms and pathogens. Disinfection, the principal mechanism for the inactivation of pathogenic organisms, is inhibited by the high concentrations of suspended solids (SS) usually present in these combined sewer overflows (CSOs). Some form of pretreatment for solids removal, therefore, is necessary for the effective disinfection of CSOs.

Sedimentation is one of the most widely used techniques for removal of solids from aqueous streams. Because of the small size (approximately $1 \mu \mathrm{m}$ ) of fecal coliform bacterial cells, however, only those sorbed onto the larger solids are removed by sedimentation. Schillinger and Gannon (1982) observed that 50 percent of the fecal coliform bacteria in a stormwater suspension were not attached to solids. These free-floating cells can behave like fine clay particles in terms of surface transport and settling characteristics. They have very slow settling velocities and may remain in suspension for days or even weeks. Thus, treatment steps following sedimentation must be able to inactivate indicator organisms and pathogens.

For large-scale operations, chemical disinfection techniques are generally favored over other methods. Chemical techniques inactivate microorganisms through oxidation, and conventional disinfectants (e.g., chlorine gas, hypochlorite) offer rapid oxidation capabilities at a relatively low cost. However, due to the adverse impact of traditional disinfectant by-products (DBPs) on human and aquatic life, more environmentally friendly chemical, physical, and/or combination methods are being pursued. Other oxygenated compounds used in disinfection include peracetic acid, ozone, chlorine 
Work by Cho et al. (2004) has shown that the rate of inactivation of $E$. coli is directly proportional to the steady-state concentration of hydroxyl radicals in the system. dioxide, and hydrogen peroxide. Physical techniques may also be employed; these include $\mathrm{UV}$ radiation and sunlight. Ozone/UV radiation and $\mathrm{UV} / \mathrm{TiO}_{2}$ are two examples of mixed-disinfection techniques. Another example of a hybrid technique is $\mathrm{O}_{3} / \mathrm{H}_{2} \mathrm{O}_{2}$ and ultrasonic cavitation (Jyoti \& Pandit, 2004).

Beltran-Heredia et al. (2001) conducted a comparative study of the abilities of 12 chemical oxidation processes to degrade p-hydroxybenzoic acid. The processes were ranked according to the degree of degradation attained at 5 and 10 minutes of reaction time. The resulting ranking, in order of increasing efficiency, was:

$\mathrm{UV}<\mathrm{UV} / \mathrm{TiO}_{2}<\mathrm{O}_{3}<\mathrm{O}_{3} / \mathrm{Fe}^{+2}=\mathrm{O}_{3} / \mathrm{H}_{2} \mathrm{O}_{2}<\mathrm{O}_{3} / \mathrm{UV}<\mathrm{UV} / \mathrm{H}_{2} \mathrm{O}_{2}=$ $\mathrm{O}_{3} / \mathrm{H}_{2} \mathrm{O}_{2} / \mathrm{Fe}^{+2}<\mathrm{H}_{2} \mathrm{O}_{2} / \mathrm{Fe}^{+2}$ (Fenton's Reagent) $<\mathrm{UV} / \mathrm{H}_{2} \mathrm{O}_{2} / \mathrm{O}_{3}<$ $\mathrm{H}_{2} \mathrm{O}_{2} / \mathrm{Fe}^{+2} / \mathrm{UV}<\mathrm{O}_{3} / \mathrm{UV} / \mathrm{H}_{2} \mathrm{O}_{2} / \mathrm{Fe}^{+2}$

This ranking indicates that the most effective methods are those that generate free radicals, primarily hydroxyl radicals $\left(\mathrm{OH}^{\bullet}\right)$. Such methods are also expected to be the most effective disinfectants. The effectiveness of hydroxyl radicals in disinfection has been demonstrated by measuring the inactivation of Escherichia coli (E. coli). Work by Cho et al. (2004) has shown that the rate of inactivation of $E$. coli is directly proportional to the steady-state concentration of hydroxyl radicals in the system. They were able to achieve a $2 \log E$. coli inactivation with an $\mathrm{OH}^{\bullet}$ concentration of $0.8 \times 10^{-5} \mathrm{mg} / \mathrm{L} \mathrm{min}$.

Hydroxyl radicals can be generated readily and inexpensively by the decomposition of $\mathrm{H}_{2} \mathrm{O}_{2}$ :

$\mathrm{H}_{2} \mathrm{O}_{2} \rightarrow \mathrm{H}_{2} \mathrm{O}+\mathrm{O}^{\bullet}$

$\mathrm{O}^{\bullet}+\mathrm{H}_{2} \mathrm{O} \rightarrow 2 \mathrm{OH}^{\bullet}$

In the absence of a catalyst, however, the rate of radical production is slow. Fenton's Reagent, on the other hand, is an extremely efficient producer of hydroxyl radicals. Its oxidation potential is 2.7 e.v., compared to 1.8 e.v. for hydrogen peroxide. The generation of $\mathrm{OH}^{\bullet}$ radicals by Fenton's Reagent involves the following reactions: $\mathrm{H}_{2} \mathrm{O}_{2}+\mathrm{Fe}^{+2} \rightarrow \mathrm{Fe}^{+3}+\mathrm{OH}^{-}+\mathrm{OH}^{\bullet}$ $\mathrm{H}_{2} \mathrm{O}_{2}+\mathrm{Fe}^{+3} \rightarrow \mathrm{Fe}^{+2}+\mathrm{H}^{+}+\mathrm{HO}_{2}^{\bullet}$ $\mathrm{Fe}^{+3}+\mathrm{HO}_{2}^{\bullet} \rightarrow \mathrm{Fe}^{+2}+\mathrm{H}^{+}+\mathrm{O}_{2}$

This process is very sensitive to the $\mathrm{pH}$, the ratio of $\mathrm{Fe}^{+2}$ to $\mathrm{H}_{2} \mathrm{O}_{2}$, and the concentration of the catalyst $\mathrm{Fe}^{+2}$. The $\mathrm{pH}$ of the system must be maintained between 4 and 6. Typical $\mathrm{Fe}^{+2}$ to $\mathrm{H}_{2} \mathrm{O}_{2}$ ratios are 1 to 5-10 wt/wt, although $\mathrm{Fe}^{2+}$ levels less than 25 to $50 \mathrm{mg} / \mathrm{L}$ can require excessive (10 to 24 hours) reaction times for $\mathrm{OH}^{\bullet}$ production (Fieser \& Fieser, 1982).

Removal of iron from the Fenton's Reagent catalytic cycle may pose problems. For example, efficiency may be reduced if $\mathrm{Fe}^{2+}$ is sequestered by oxidation products such as organic acids, which may form via reaction with the dissolved organic matter (DOM) in the aqueous system. Other known iron-complexing agents, such as phosphates, ethylenediaminetetraacetic acid (EDTA), formaldehyde, and citric/oxalic acids, can also affect performance. Thus, the efficiency of Fenton's Reagent appears to be controlled primarily by the concentration of the catalyst $\left(\mathrm{Fe}^{+2}\right)$ and the composition of the aqueous medium.

Although Fenton's Reagent has been used for the oxidation of many compounds, its potential for water disinfection has not been explored. This project was undertaken to examine the feasibility of using Fenton's Reagent as a disinfectant for E. coli in CSO samples and to compare its effectiveness with that of hydrogen peroxide alone under 
similar concentrations and conditions. Because of the above-mentioned effects of iron sequestration in environmental samples, various $\mathrm{Fe}^{2+}$ concentrations were tested. A series of contact times was also investigated, and the possible utility of Fenton's Reagent as a disinfection method is explored.

\section{MATERIALS AND METHODS}

\section{Materials}

All glassware was thoroughly cleaned with a phosphate-free detergent and hot $\left(90^{\circ} \mathrm{C}\right)$ water (Standard Methods 9030) and rinsed with hot $\left(90^{\circ} \mathrm{C}\right)$ water to remove all traces of detergent, followed by rinsing with laboratory-pure water and sterilization at $170^{\circ} \mathrm{C}$ for two hours (Standard Methods 9040). Only deionized and sterilized (Standard Methods 9060A) water was used in all experiments.

All test samples, before and after treatment, were collected in nonreactive, precleaned, and sterilized (Standard Methods 9050A) borosilicate glass or plastic bottles. Samples of combined sewage were collected at the water treatment facility in Perth Amboy, New Jersey. The samples were allowed to stand for two hours at room temperature and then decanted using a siphon hose. The decanted samples were well mixed, analyzed, and stored at $4^{\circ} \mathrm{C}$. The settled, decanted, and mixed CSO sample used for this study contained $290 \mathrm{mg} / \mathrm{L}$ of dissolved organic carbon (DOC), $28 \mathrm{mg} / \mathrm{L}$ of total suspended solids (TSS), and 2.6 to $7.5 \times 10^{6}$ colony forming units (CFU) $/ 100 \mathrm{~mL}$ of E. coli.

The $\mathrm{Fe}^{2+}$ catalyst for the Fenton's Reagent was prepared by dissolving $69.50 \mathrm{~g}$ of analytical-grade ferrous sulfate $\left(\mathrm{FeSO}_{4} \cdot 7 \mathrm{H}_{2} \mathrm{O}\right)$ in $500 \mathrm{~mL}$ of sterilized deionized water (DI) containing $5 \mathrm{~mL}$ of concentrated $\mathrm{H}_{2} \mathrm{SO}_{4}$ (Weast, 1980). Thirty percent hydrogen peroxide of analytical grade was used both to produce the Fenton's Reagent and as an oxidizing agent without $\mathrm{Fe}^{2+}$.

\section{Experimental Procedures}

Disinfection tests were carried out using four different compositions of Fenton's Reagent (Exhibit 1) and five contact times. Comparison tests were carried out with hydrogen peroxide alone. The efficiency of disinfection was measured by the difference in the densities of $E$. coli before and after exposure to the disinfectant. Samples were preserved for microbial analyses by adding $1.5 \mathrm{~mL}$ of 10 percent sodium thiosulfate solution

Exhibit 1. Molar ratios of $\mathrm{Fe}^{+2}$ and $\mathrm{H}_{2} \mathrm{O}_{2}$ in the Fenton's Reagent

\begin{tabular}{lccc}
\hline & $\begin{array}{c}\mathrm{Fe}(\mathrm{aq})^{+2} \text { to } \\
\text { Dose } \\
\mathbf{H}_{2} \mathbf{0}_{2} \text { Ratio }\end{array}$ & $\begin{array}{c}\mathrm{mL} \text { of } \mathrm{Fe}(\mathrm{aq})^{+2} \\
\text { Added to 2-L CSO Sample }\end{array}$ & $\begin{array}{c}\mathrm{mL} \text { of } \mathrm{H}_{2} \mathbf{O}_{2} \\
\text { Added to 2-L CSO Sample }\end{array}$ \\
1 & $1: 2$ & 15 & 1.5 \\
2 & $1: 9$ & 15 & 9 \\
3 & $1: 14$ & 15 & 14 \\
4 & $1: 18$ & 15 & 18
\end{tabular}


Exhibit 2. Disinfection of E. coli by Fenton's Reagent at $25^{\circ} \mathrm{C}, \mathrm{pH} 5.90-6.2 / \mathrm{L}$ CSO sample/jar

\begin{tabular}{lccccc}
\hline $\begin{array}{l}\text { Time } \\
\text { (Min.) }\end{array}$ & $\begin{array}{c}\text { Jar 2 } \\
\text { No Fenton's Reagent }\end{array}$ & $\begin{array}{c}\text { Jar 3 } \\
\text { (Dose 1) }\end{array}$ & $\begin{array}{c}\text { Jar 4 } \\
\text { (Dose 2) }\end{array}$ & $\begin{array}{c}\text { Jar 5 } \\
\text { (Dose 3) }\end{array}$ & $\begin{array}{c}\text { Jar 6 } \\
\text { (Dose 4) }\end{array}$ \\
0 & $2.81 \times 10^{6}$ & $2.21 \times 10^{6}$ & $2.18 \times 10^{6}$ & $2.89 \times 10^{6}$ & $2.89 \times 10^{6}$ \\
0.5 & $4.0 \times 10^{6}$ & ND & ND & ND & ND \\
1.0 & $5.10 \times 10^{6}$ & ND & ND & ND & ND \\
5.0 & $3.39 \times 10^{6}$ & ND & ND & ND & ND \\
10.0 & $3.05 \times 10^{6}$ & ND & ND & ND & ND \\
30.0 & $3.28 \times 10^{6}$ & ND & ND & ND & ND \\
\hline
\end{tabular}

$\mathrm{ND}=$ Not Detected

per $100 \mathrm{~mL}$ of sample and cooled to maintain a temperature below $10^{\circ} \mathrm{C}$ (Standard Methods 9060B). E. coli was analyzed by the membrane filter procedure (Standard Methods 9222B; Clesceri et al., 1988). The CSO sample used for the Fenton's experiments had an average starting E. coli concentration of $3.8 \times 10^{6} \mathrm{CFU} / 100 \mathrm{~mL}$.

For the Fenton's experiments, a 2-L laboratory blank was withdrawn from the settled CSO stock solution, sterilized, and placed in a jar (Jar 1). The remaining 10-L sample was split into five 2-L jars (Jars 2 to 6). Jar 2 was not treated with Fenton's Reagent and was used as the laboratory control sample. Jars 3 to 6 were each inoculated with a different dose of Fenton's Reagent (Exhibit 2). Ratios of iron to hydrogen peroxide were chosen to be the range commonly used for chemical oxidation. All six jars were sampled for $E$. coli densities (Standard Methods 9222B) before the addition of the disinfecting agent (at "0 min").

The specified amount of $\mathrm{FeSO}_{4}$ solution (Exhibit 1) was added to each 2-L CSO sample, and the $\mathrm{pH}$ of the mixture was noted. The $\mathrm{pH}$ was then adjusted to 6.0 by $1 \mathrm{~N}$ $\mathrm{NaOH}$ solution. The specified amount of 30 percent $\mathrm{H}_{2} \mathrm{O}_{2}$ (Exhibit 2) was then added to the mixture and the temperature was recorded. The timing of the sample's exposure to the disinfectant was initiated upon the addition of $\mathrm{H}_{2} \mathrm{O}_{2}$. At several contact times $(0,0.5$, 1, 5, 10, and 30 minutes), samples were withdrawn from each of the six jars. After 30 minutes of contact time, Jars 3 to 6 were tested for the presence/absence of residual oxidizing agents with potassium iodide-starch paper.

For the hydrogen peroxide tests, either $2 \mathrm{~mL}$ or $4 \mathrm{~mL}$ of 30 percent $\mathrm{H}_{2} \mathrm{O}_{2}$ were added, and samples were withdrawn at 0,5 , and 10 minutes. Three sets of tests were performed. The $\mathrm{pH}$ was not adjusted, but the $\mathrm{pH}$ of all the samples was within the range (6.9 to 7.4) where hydrogen peroxide is expected to be an effective disinfectant. As with the Fenton's samples, potassium iodide-starch paper was used to test for the presence/absence of oxidizing agent(s).

\section{RESULTS AND DISCUSSION}

Addition of the Fenton's Reagent caused the concentrations of $E$. coli to drop below the detection limit within 0.5 minutes (Exhibit 2 and 3). This near-instantaneous inactivation was achieved at a $\mathrm{pH}$ of approximately 6.0 , irrespective of the $\mathrm{Fe}^{+2}$ to $\mathrm{H}_{2} \mathrm{O}_{2}$ molar ratio 


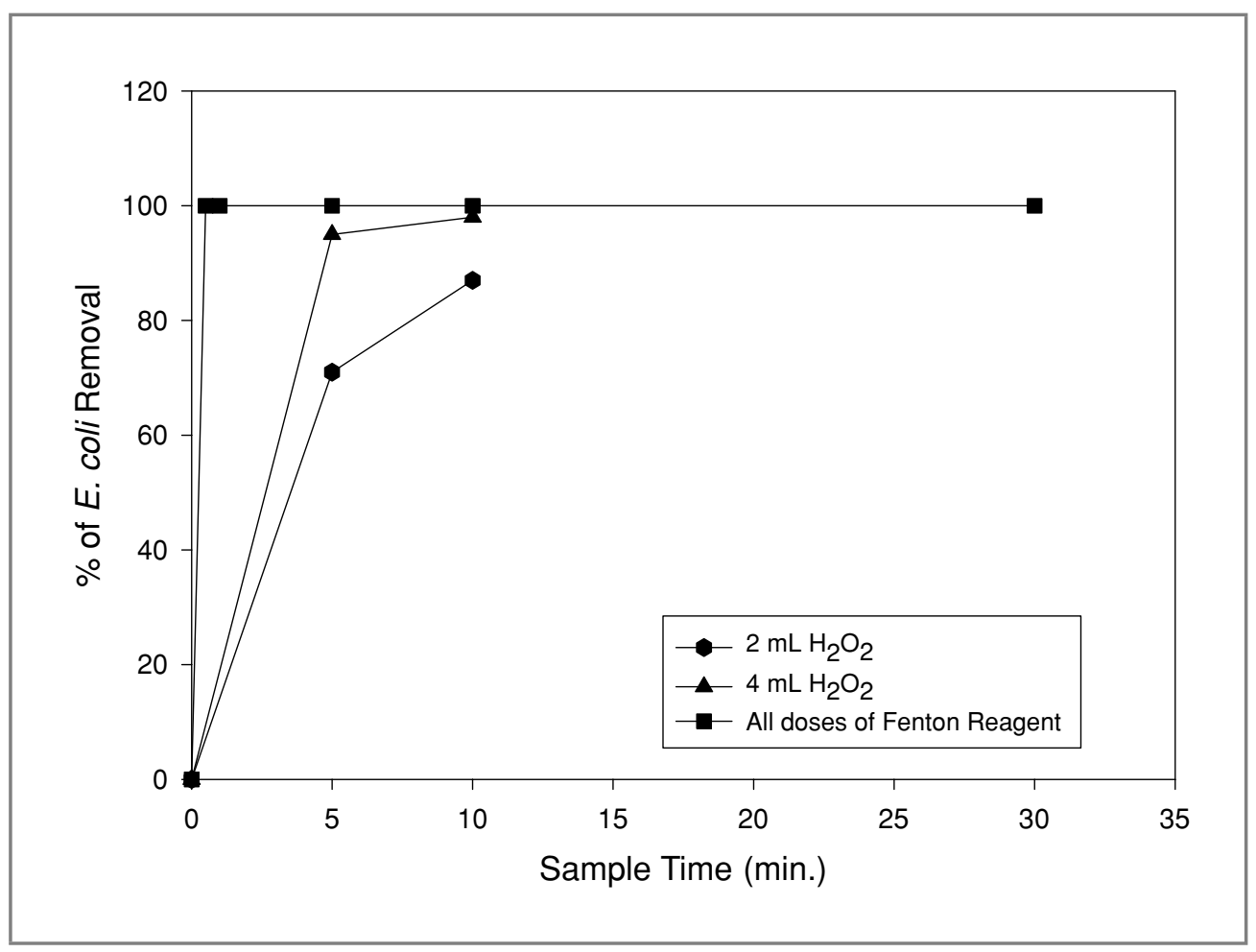

Exhibit 3. Comparison of disinfection by $\mathrm{H}_{2} \mathrm{O}_{2}$ and Fenton's Reagent

used. Also, at this $\mathrm{pH}$, no precipitation of iron hydroxide/oxide was observed. Clearly, Fenton's Reagent was a rapid and efficient disinfectant for E. coli in the settled CSO samples studied.

The presence of organic matter (DOC) affects the efficiency of Fenton's Reagent by consuming $\mathrm{OH}^{\bullet}$ radicals (Bogan \& Trbovic, 2003; Murry \& Parson, 2004) and chelating the $\mathrm{Fe}^{+3}$ and $\mathrm{Fe}^{+2}$ ions. However, the concentration of DOC in the settled CSO samples examined in this study did not appear to affect the performance of the Fenton's Reagent. This demonstrates that the composition of the CSO studied is amenable to treatment with Fenton's Reagent. Moreover, after 30 min of reaction time, the treated jars (Jars 3 to 6) showed the presence of oxidizing agent(s). Such residual oxidant(s) will likely inhibit E. coli regrowth in a manner analogous to the residual chlorine in the chlorine disinfection process. However, unlike chlorine-bearing oxidants, Fenton's Reagent is unlikely to form deleterious DBPs. Murry and Parson (2004) showed that when natural organic matter (NOM) in drinking-water sources is treated with Fenton's Reagent, subsequent chlorination does not produce trihalomethane (THM)-type by-products.

In contrast to the Fenton's Reagent, disinfection of $E$. coli by $\mathrm{H}_{2} \mathrm{O}_{2}$ was not only slow but also incomplete (Exhibits 3 and 4). Hydrogen peroxide has also been found to be inferior to Fenton's Reagent in various chemical reactions. For example, Barbusiński and Filipek (2003) found Fenton's Reagent to be more efficient than hydrogen peroxide in aerobic sludge digestion. Crystal Violet was shown to be poorly degraded by UV light or hydrogen peroxide (Chen et al., 2001), but was quickly broken down by Fenton's Reagent. Also, Chen et al. (2001) found that Fenton's Reagent was able to completely dechlorinate aqueous-phase trichloroethene (TCE), with and without the presence of soil, 
Exhibit 4. Disinfection of E. coli by hydrogen peroxide (30\% solution)

\begin{tabular}{|c|c|c|c|c|c|}
\hline \multirow[t]{2}{*}{ Trial } & \multirow[t]{2}{*}{ Contact Time (Min.) } & \multicolumn{2}{|c|}{ 2-mL $\mathrm{H}_{2} \mathrm{O}_{2} / 2-\mathrm{L}$ Sample } & \multicolumn{2}{|c|}{ 4-mL $\mathrm{H}_{2} \mathrm{O}_{2} / 2$-L Sample } \\
\hline & & E. coli ${ }^{\mathrm{a}}$ & $\mathrm{pH}$ & E. coli ${ }^{\mathrm{a}}$ & $\mathrm{pH}$ \\
\hline \multirow[t]{4}{*}{1} & Pre-disinfectant & $7.5 \times 10^{6}$ & NA & $7.5 \times 10^{6}$ & NA \\
\hline & 0 (immediate sampling) & $1.5 \times 10^{6}$ & 7.4 & $2.0 \times 10^{6}$ & 7.1 \\
\hline & 5 & $4.5 \times 10^{5}$ & 7.3 & $1.9 \times 10^{5}$ & 7.0 \\
\hline & 10 & $2.6 \times 10^{5}$ & 7.0 & $2.3 \times 10^{4}$ & 7.0 \\
\hline \multirow[t]{4}{*}{2} & Pre-disinfectant & $7.8 \times 10^{6}$ & NA & $7.8 \times 10^{6}$ & NA \\
\hline & 0 & $2.4 \times 10^{6}$ & 7.4 & $1.4 \times 10^{6}$ & 7.4 \\
\hline & 5 & $7.8 \times 10^{5}$ & 7.4 & $4.4 \times 10^{5}$ & 7.3 \\
\hline & 10 & $5.2 \times 10^{5}$ & 7.4 & $1.0 \times 10^{5}$ & 7.2 \\
\hline \multirow[t]{4}{*}{3} & Pre-disinfectant & $5.8 \times 10^{6}$ & NA & $5.8 \times 10^{6}$ & NA \\
\hline & 0 & NA & 7.4 & $6.6 \times 10^{5}$ & 7.1 \\
\hline & 5 & $1.5 \times 10^{6}$ & 7.3 & $3.4 \times 10^{5}$ & 6.9 \\
\hline & 10 & $4.8 \times 10^{4}$ & 7.2 & $1.0 \times 10^{3}$ & 7.1 \\
\hline
\end{tabular}

and without the formation of volatile organic compound (VOC) intermediates or by-products. When they applied high concentrations of $\mathrm{H}_{2} \mathrm{O}_{2}$ without $\mathrm{Fe}^{+2}$, about 70 percent of the dissolved TCE was sparged without being oxidized. These findings are in line with the known oxidation potentials of Fenton's Reagent and $\mathrm{H}_{2} \mathrm{O}_{2}$ (2.70 and 1.77 e.v., respectively).

Fenton's Reagent has been shown to be useful in removing various constituents from wastewater, such as chemical oxygen demand (COD; San Sebastian et al., 2003), pesticides (Barbusiński \& Filipek, 2001), and NOM (Murry \& Parson, 2004).

Furthermore, Andrzejewski and Kulik (2007) have shown that Fenton's Reagent does not react with dimethylamine (DMA), which is often found in source water and is a precursor of N-Nitrosodimethyl amine (NDMA), a known carcinogen. Other common oxidizing agents, including $\mathrm{H}_{2} \mathrm{O}_{2}$ and chlorine-bearing compounds, will react with DMA and produce NDMA (Andrzejewski \& Narwrocki, 2007). Thus, from a health perspective, Fenton's Reagent would be a superior choice.

Taken together with the established literature and uses of Fenton's Reagent, this study shows the potential for multiple uses of Fenton's Reagent. By incorporating Fenton's Reagent into a CSO treatment regimen, water may be simultaneously disinfected and treated for organic contaminants.

\section{CONCLUSIONS}

The results of this study show that rapid (less than 1 minute) disinfection of settled CSO samples can be achieved at a $\mathrm{pH}$ of 5.9 to 6.2. The primary advantage of Fenton's Reagent over chlorine-based disinfectants is the prevention of regrowth potential without the 
formation of deleterious DBP. In the case of $\mathrm{H}_{2} \mathrm{O}_{2}$ alone, the disinfection was not only incomplete after 10 minutes of contact, but the rate was much slower. Incorporation of Fenton's Reagent into CSO treatment procedures could potentially achieve disinfection in addition to its well-known capacity for oxidation of organic compounds.

\section{DISCLAIMER}

Any opinions expressed in this article are those of the authors and do not necessarily reflect the official positions and policies of the US EPA. Any mention of products or trade names does not constitute recommendation for use by the US EPA.

\section{REFERENCES}

Andrzejewski, P., \& Kulik, N. (2007). The hazard of N-nitrosoamines formation during short chain secondary amines (DMA, MEA, and DEA) reactions with catalyzed and non-catalyzed hydrogen peroxide. Presented at the 10th International Conference on Environmental Science and Technology, Kos Island, Greece.

Andrzejewski, P., \& Narwrocki, J. (2007). N-nitrosodimethylamine formation during treatment with strong oxidants of dimethylamine containing water. Water Science \& Technology, 56(12), 125-131.

Barbusiński, K., \& Filipek, K. (2001). Use of Fenton's Reagent for removal of pesticides from industrial wastewater. Polish Journal of Environmental Studies, 10(4), 207-212.

Barbusiński, K., \& Filipek, K. (2003). Aerobic sludge digestion in the presence of hydrogen peroxide and Fenton's reagent. Polish Journal of Environmental Studies, 12(1), 35-40.

Beltran-Heredia, J., Torregrosa, J., Dominguez, J. R., \& Peres, J. A. (2001). Comparison of the degradation of p-hydroxybenzoic acid in aqueous solution by several oxidation processes. Chemosphere, 42, 351-359.

Bogan, B. W., \& Trbovic, V. (2003). Effect of sequestration on PAH degradability with Fenton's reagent: Roles of total organic carbon, humin, and soil porosity. Journal of Hazardous Materials, B100, 285-300.

Chen, G., Hoag, G. E., Chedda, P., Nadim, F., Woody, B. A., \& Dobbs, G. M. (2001). The mechanism and applicability of in situ oxidation of trichloroethylene with Fenton's Reagent. Journal of Hazardous Materials, B87, 171-186.

Cho, M., Chung, H., Choi, W., \& Yoon, J. (2004). Linear correlation between inactivation of E. coli and OH radical concentration in $\mathrm{TiO}_{2}$ photocatalytic disinfection. Water Research, 38, 1069-1077.

Clesceri, L. S., Greenberg, A. E., \& Eaton, A. D. (1988). Standard methods for the examination of water and wastewater (20th ed.). Washington, DC: American Public Health Association.

Fieser, L., \& Fieser, M. (1982). Reagents for organic synthesis. New York: Wiley.

Jyoti, K. K., \& Pandit, A. B. (2004). Effect of cavitations on chemical disinfection efficiency. Water Research, $38,2249-2258$.

Murry, C. A., \& Parson, S. A. (2004). Removal of NOM from drinking water: Fenton's and photo-Fenton's processes. Chemosphere, 54, 1017-1023.

San Sebastian, M., Fíguls Fernández, J., Font Segura, X., \& Sánchez Ferrer, A. (2003). Pre-oxidation of an extremely polluted industrial wastewater by the Fenton's reagent. Journal of Hazardous Materials, 101, 315-322. 
Schillinger, J., \& Gannon, J. (1982). Coliform attachment to suspended particles in stormwater. NTIS PB

83-108324. Washington, DC: US EPA.

Weast, R. C. (Ed.). (1980). Handbook of chemistry and physics (60th ed.). Boca Raton, FL: CRC Press.

Ariamalar Selvakumar has more than 19 years of experience working in the environmental engineering field. She is currently an environmental engineer with the US EPA Urban Watershed Management Branch in Edison, New Jersey. She holds a PhD in civil and environmental engineering from the New Jersey Institute of Technology and a M.Eng. in environmental engineering from the Asian Institute of Technology in Bangkok, Thailand. She also holds a B.Eng. (Hons.) in civil engineering from University of Peradeniya, Sri Lanka. Her current research interests are rehabilitation of aging water infrastructure. She has authored, coauthored, or presented a combination of more than 40 peer-reviewed journal articles, conference proceedings, posters, and US EPA reports.

Mary Ellen Tuccillo, PhD, is a senior environmental scientist with the Cadmus Group in Watertown, Massachusetts. She holds a BS in geology from Yale University, an MS in geology from the University of Michigan, and a PhD in environmental sciences from the University of Virginia. Dr. Tuccillo's focus is geochemistry, and her research experiences have included iron reduction in groundwater and heavy metals in stormwater runoff.

Swarna Muthukrishnan, PhD, was formerly an Oak Ridge Institute for Science and Education (ORISE) Postdoctoral Research Fellow at the US EPA's Office of Research and Development in Edison, New Jersey. At the US EPA, she worked on urban wet-weather flow management focusing on stressor attenuation using stormwater best management practices. She is presently at American Water in New Jersey and is engaged in research activities on optimization of membrane technology applications in wastewater treatment and reuse.

Asim B. Ray, D.Sc., is a technical scientist with the US EPA National Risk Management Research Laboratory, Water Supply and Water Resource Division, Urban Watershed Management Branch in Edison, New Jersey. His research interests include use of biomass in the removals of heavy metals, toxic organic compounds, pathogens, and emerging contaminants from aqueous media. Several papers involving the above contaminants have been published and are under preparation. All these projects are under US EPA sponsorship. 